\title{
Reduction and Methyl Transfer Kinetics of the Alpha Subunit from Acetyl- Coenzyme A Synthase
}

\author{
Xiangshi Tan, Christopher Sewell, Qingwu Yang, and Paul A. Lindahl* \\ Department of Chemistry and of Biochemistry \& Biophysics, Texas A \& M University, College Station, Texas 77843 \\ RECEIVED DATE (will be automatically inserted after manuscript is accepted)
}

Acetyl-coenzyme A synthase is a bifunctional enzyme found in anaerobic archaea and bacteria that grow autotrophically on simple inorganic compounds such as $\mathrm{CO}_{2} / \mathrm{H}_{2}$ or $\mathrm{CO}$. The enzyme from Moorella thermoacetica (ACS) is an $\alpha_{2} \beta_{2}$ tetramer containing two unique Ni-Fe-S active sites connected by a molecular tunnel. ${ }^{1,2}$ The $\mathrm{Ni}_{1} \mathrm{Fe}_{4} \mathrm{~S}_{4-5}$ C-cluster catalyzes the reversible reduction of $\mathrm{CO}_{2}$ to $\mathrm{CO}$ and is located in the $\beta$ subunit. $\mathrm{CO}$ generated at this site migrates through the tunnel to the Acluster, located in $\alpha$, where it reacts with CoA and a methyl group to generate acetyl-CoA. During catalysis, the two sites are mechanistically coupled.

The oxidized form of the A-cluster has a $\mathrm{Ni}^{2+}$ ion bridged to an $\left[\mathrm{Fe}_{4} \mathrm{~S}_{4}\right]^{2+}$ cubane, reportedly via a Cu complex. ${ }^{2}$ During catalysis, a methyl cation from a corrinoid-iron-sulfur protein $\left(\mathrm{CH}_{3}-\right.$ $\mathrm{Co}^{3+} \mathrm{FeSP}$ or $\left.\mathrm{Me}-\mathrm{CP}\right)$ transfers, presumably to the Ni. We favor a mechanism in which $\mathrm{CO}$ inserts into the $\mathrm{CH}_{3}-\mathrm{Ni}$ bond, and nucleophilic attack by $\mathrm{CoA}$ on the resulting $\mathrm{CH}_{3} \mathrm{C}(\mathrm{O})$-Ni group yields acetyl-CoA. ${ }^{1}$ Methyl transfer cannot occur unless a site on the enzyme is reduced. This so-called D-site has been suggested to consist of a redox-active cystine/dicysteinate pair closely associated with the $\mathrm{Ni}^{3}$ The $2 \mathrm{e}^{-}$-reduced $\mathrm{D}_{\text {red }}$ state transfers those electrons to $\mathrm{Ni}^{2+}$ as the methyl cation binds, reaction [1].

$\left[\mathrm{Ni}^{2+} \mathrm{D}_{\text {red }}\right]+\mathrm{CH}_{3}-\mathrm{Co}^{3+} \mathrm{FeSP} \rightleftarrows\left[\mathrm{CH}_{3}-\mathrm{Ni}^{2+} \mathrm{D}_{\mathrm{ox}}\right]+\mathrm{Co}^{1+} \mathrm{FeSP}$

The kinetics of this process has been studied by stopped-flow. ${ }^{4,5}$ In this technique, solutions of reactants are rapidly mixed and a reaction-sensitive chromophore is monitored by UV-vis spectroscopy. Reaction [1] can be monitored at $390 \mathrm{~nm}$ or 450 $\mathrm{nm}$, wavelengths sensitive to CoFeSP. Fitting the data required a three-step model involving: a) docking of ACS and $\mathrm{CH}_{3}$ $\mathrm{Co}^{3+} \mathrm{FeSP}$; b) methyl transfer, and c) undocking of the two proteins. ${ }^{5}$ Apparent overall forward and reverse second-order rate constants corresponding to [1] $\left(\mathrm{k}_{\mathrm{f}} \sim 12 \mu \mathrm{M}^{-1} \mathrm{sec}^{-1} ; \mathrm{k}_{\mathrm{r}} \sim 2 \mu \mathrm{M}^{-1} \mathrm{sec}^{-}\right.$ $\left.{ }^{1}\right)$ indicate that methyl transfer was reversible $\left(\mathrm{K}_{\mathrm{eq}} \sim 6\right)$ and fast.

The $\alpha$ subunit of ACS can be cloned and overexpressed in $E$. coli. ${ }^{6}$ Using $\mathrm{CO}$ as a substrate, recombinant $\alpha$ catalyzes the synthesis of acetyl-CoA, but at a rate $\sim 10$-times slower than ACS. The catalytic mechanism used by $\alpha$ is undoubtedly similar to that used by ACS, allowing mechanistic investigations unfettered by the $\beta$ subunit. The goals of this study were to investigate the roles of the $\mathrm{Fe}_{4} \mathrm{~S}_{4}$ component of the A-cluster and the D-site, and to understand the relationship between the two, if any. For example, this component could be the D-site itself or an electron transfer conduit for reducing it.

We wondered whether the methyl group of $\mathrm{CH}_{3}-\mathrm{Co}^{3+} \mathrm{FeSP}$ also transferred reversibly to isolated $\alpha$. To evaluate this, $\alpha$ was preincubated in $\mathrm{Ti}^{3+}$ citrate (to reduce $\mathrm{D}_{\mathrm{ox}}$ ) and then reacted with $\mathrm{CH}_{3}-\mathrm{Co}^{3+} \mathrm{FeSP}^{7}$ The data (Figure 1A) demonstrated that the methyl group transferred, albeit slower than with ACS. The reaction was completed within $\sim 1 \mathrm{sec}$ (the equivalent reaction with ACS completes within $\sim 0.2 \mathrm{sec}$ ). Nearly identical rates were obtained at $450 \mathrm{~nm}$. The methyl group also transferred in the reverse direction, from $\mathrm{CH}_{3}-\alpha$ to $\mathrm{Co}^{1+} \mathrm{FeSP}$ (Figure 1B), again at rates significantly slower than with ACS. Experiments were repeated using various protein concentrations (Table 1). Previously described kinetic data fitting procedures and criteria were employed. ${ }^{5}$ Differential equations were generated from models and numerically integrated using a set of candidate rateconstants. Simulations were fitted using the Simulated Annealing algorithm. In contrast to the situation with ACS, methyl group transfer data could be simulated assuming a single reaction, namely [1]. Optimized $\mathrm{k}_{\mathrm{f}}$ and $\mathrm{k}_{\mathrm{r}}$ were $\sim 7$ and 14 times smaller than with ACS, and $\mathrm{K}_{\text {eq }}(\sim 11)$ was $\sim 2$-times larger.

Next we explored the role of the $\mathrm{Fe}_{4} \mathrm{~S}_{4}$ component of the Acluster in catalysis. In previous studies, this component was found to be reducible by low-potential reductants such as dithionite and $\mathrm{Ti}^{3+}{ }^{3+}$ itrate. ${ }^{8}$ To examine the kinetics of this process, oxidized $\alpha_{\mathrm{ox}}$ was mixed with $1 \mathrm{mM} \mathrm{Ti}^{3+}$ citrate, and monitored by stopped-flow at $420 \mathrm{~nm}$, where $\left[\mathrm{Fe}_{4} \mathrm{~S}_{4}\right]^{2+}$ clusters exhibit a broad absorption shoulder. ${ }^{9}$ As these clusters become reduced to the $1+$ core state, absorption declines. Reduction occurred slowly and was completed after $\sim 300 \mathrm{sec}$ (Figure 1C). This rate was about 200fold slower than that of methyl group transfer. The reaction was repeated at various concentrations of $\alpha_{o x}$; the decline was monophasic and first-order in $\alpha_{\mathrm{ox}}\left(\mathrm{k}_{\mathrm{app}}\right.$ was invariant at $\left.\sim 0.02 \mathrm{sec}^{-1}\right)$. The calculated extinction coefficient for reduction $\left(\varepsilon=4000 \mathrm{M}^{-1}\right.$ $\mathrm{cm}^{-1}$ ) was similar to that reported for ferredoxins and previous $\alpha$ subunit preparations. ${ }^{6,8,9}$ The equivalent reaction was performed using $\alpha_{o x}$ that had not been activated with $\mathrm{NiCl}_{2}$. This state, equivalent to phenanthroline-treated ACS, lacks labile Ni, acetylCoA synthase activity, the NiFeC EPR signal, and methyl group transfer ability. ${ }^{1}$ Reduction was also mono-phasic, suggesting that both labile and nonlabile clusters were reduced at essentially the same rate $\left(\sim 0.02 \mathrm{sec}^{-1}\right.$ or $\left.2.5 \pm 0.5 \times 10^{-5} \mu \mathrm{M}^{-1} \mathrm{sec}^{-1}\right)$.

At this point, we knew that $\left[\mathrm{Fe}_{4} \mathrm{~S}_{4}\right]^{2+}$ reduction was much slower than methyl group transfer, not whether it was slower than $\mathrm{D}_{\mathrm{ox}}$ reduction. To determine this, oxidized $\alpha_{\mathrm{ox}}$ was mixed simultaneously with both $\mathrm{Ti}^{3+}$ citrate and $\mathrm{CH}_{3}-\mathrm{Co}^{3+} \mathrm{FeSP}$, and the reaction was followed at $390 \mathrm{~nm}$ where both methyl group transfer and $\left[\mathrm{Fe}_{4} \mathrm{~S}_{4}\right]^{2+}$ reduction could be monitored. Results (Figure 1D) showed an initial rapid increase in absorbance, due to methyl transfer, followed by a slow decline due to $\left[\mathrm{Fe}_{4} \mathrm{~S}_{4}\right]^{2+}$ reduction. Thus, the $\left[\mathrm{Fe}_{4} \mathrm{~S}_{4}\right]^{2+}$ cube need not be reduced to the $1+$ state for the methyl group to be accepted and it is not the D-site or some portion thereof. $D_{o x}$ is reduced far faster than $\left[\mathrm{Fe}_{4} \mathrm{~S}_{4}\right]^{2+}$, probably via a pathway not involving the cube. Absolute rates for these different processes should be compared cautiously as they may depend differently on reductant or protein concentrations. The redox state of the cube had little, if any, influence on D-site reduction or methyl group transfer; methyl group transfer occurred when the cube was reduced (when $\alpha$ was 


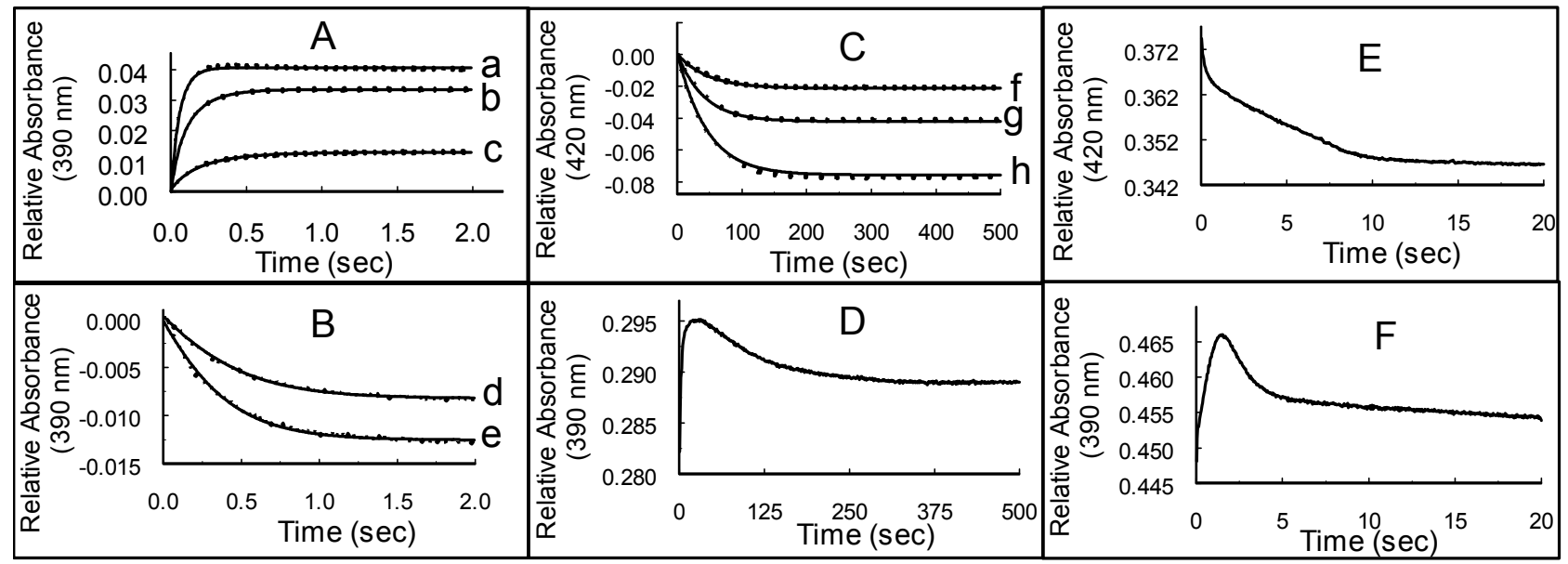

Figure 1. Stopped-Flow of ACS and Isolated $\alpha$ subunit. A, Reaction of $\alpha$ with $\mathrm{CH}_{3} \mathrm{Co}^{3+} \mathrm{FeSP}$. The $\alpha$ subunit in $50 \mathrm{mM}$ TrisHCl pH 8.0 (buffer A) was preincubated with $\mathrm{Ti}^{3+}$ citrate $(500 \mu \mathrm{M})$ for $15 \mathrm{~min}$ and then mixed with $\mathrm{CH}_{3} \mathrm{Co}^{3+} \mathrm{FeSP}$ that had been similarly pre-incubated with $\mathrm{Ti}^{3+}$ citrate $(500 \mu \mathrm{M})$ for 15 min. Solid lines, experimental curves; dashed lines, best-fit simulations using reaction [1] and parameters in Tables 1 . B, Reaction of $\mathrm{CH}_{3}-\alpha_{\mathrm{ox}}$ with $\mathrm{Co}^{1+} \mathrm{FeSP}$. Protein concentrations and simulations for a, b, c, d, e refer to No. 5, 1, 3, 8 and 7 of Table 1, respectively. $\mathbf{C}$, Reduction of $\alpha_{o x}$ with Ti ${ }^{3+}$ citrate $(1.0 \mathrm{mM})$ in buffer A. Traces $\mathrm{f}, \mathrm{g}, \mathrm{h}$, corresponding to $\left[\alpha_{\mathrm{ox}}\right]=5,10$, and $20 \mu \mathrm{M}$, respectively. $\mathbf{D}, \alpha_{\mathrm{ox}}(10.0 \mu \mathrm{M})$ mixed with $\mathrm{CH}_{3} \mathrm{Co}^{3+} \mathrm{FeSP}(5.0 \mu \mathrm{M})$ and $\mathrm{Ti}^{3+}$ citrate $(1.0 \mathrm{mM})$. E, Reduction of $\operatorname{ACS}_{\text {ox }}(10.0 \mu \mathrm{M})$ with $\mathrm{Ti}^{3+}$-citrate $(1.0 \mathrm{mM})$. F, ACS $_{\text {ox }}(10.0 \mu \mathrm{M})$ mixed with $\mathrm{CH}_{3} \mathrm{Co}^{3+} \mathrm{FeSP}(5.0 \mu \mathrm{M})$ and $\mathrm{Ti}^{3+}$ citrate $(1.0 \mathrm{mM})$. For $\mathrm{CH}_{3} \mathrm{Co}^{3+} \mathrm{FeSP}$ and $\mathrm{Co}^{1+} \mathrm{FeSP}$, extinction coefficients $(\varepsilon)$ at 390 and $450 \mathrm{~nm}$ (in $\mu \mathrm{M}^{-1} \mathrm{~cm}^{-1}$ ) were as reported. ${ }^{5}$ For $\alpha_{\text {red }}(\alpha$ was reduced by 1.0

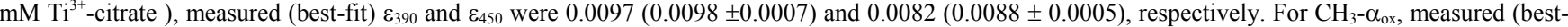
fit) $\varepsilon_{390}$ and $\varepsilon_{450}$ were $0.0128(0.0121 \pm 0.0005)$ and $0.0060(0.0061 \pm 0.0005)$, respectively.

Table 1. Methyl Transfer Reaction Parameters

\begin{tabular}{cccccccc}
\hline No. & \multicolumn{2}{c}{$\begin{array}{c}\text { Measured } \\
\mu \mathrm{M}\end{array}$} & \multicolumn{2}{c}{$\begin{array}{c}\text { Best-fit } \\
\mu \mathrm{M}\end{array}$} & $\begin{array}{c}\mathrm{k}_{\mathrm{f}} \\
\mu \mathrm{M}^{-1} \mathrm{sec}^{-1}\end{array}$ & $\begin{array}{c}\mathrm{k}_{\max } \\
\mathrm{nm}\end{array}$ \\
\hline \multicolumn{5}{c}{$\mathrm{MeCP}$} & $\alpha_{\mathrm{red}}$ & $\mathrm{MeCP}$ & {$\left[\alpha-\mathrm{Ni}_{\mathrm{L}}\right]$} \\
\hline 1 & 5.0 & 10.0 & 4.7 & 3.4 & 2.0 & 0.20 & 390 \\
2 & 5.0 & 10.0 & 5.2 & 3.5 & 2.4 & 0.10 & 450 \\
3 & 2.5 & 5.0 & 2.9 & 1.4 & 1.7 & 0.19 & 390 \\
4 & 2.5 & 5.0 & 2.6 & 1.6 & 1.8 & 0.15 & 450 \\
5 & 14.0 & 10.0 & 14.0 & 3.1 & 1.3 & 0.10 & 390 \\
6 & 14.0 & 10.0 & 14.2 & 3.2 & 1.0 & 0.10 & 450 \\
7 & 6.0 & 10.0 & 6.3 & 2.9 & 1.1 & 0.15 & 390 \\
8 & 3.0 & 10.0 & 3.0 & 2.9 & 1.5 & 0.15 & 390 \\
\hline $\mathrm{AV}$ & & & & 1.6 & 0.14 & \\
\hline SD & & & & 0.5 & 0.04 & \\
\hline
\end{tabular}

Results No. 1-6 are for the forward methyl transfer reaction, while No. 7 and 8 are for reverse reaction (protein concentrations refer to $\mathrm{Co}^{1+} \mathrm{FeSP}$ and $\mathrm{CH}_{3}-\alpha_{\text {ox }}$ rather than $\mathrm{CH}_{3} \mathrm{Co}^{3+} \mathrm{FeSP}$ and $\alpha_{\text {red }}$ ). Experiments 1-6 used one batch of proteins, while experiments 78 used a different batch of proteins. Best-fit $\left[\alpha-\mathrm{Ni}_{L}\right]$ refers to the concentration of a containing labile Nickel. Listed protein concentrations are those after mixing in the stopped-flow cell.

pre-incubated in $\mathrm{Ti}^{3+}$ citrate prior to methyl group transfer) or oxidized (as just described).

In the final set of experiments, ACS was substituted for $\alpha$ in equivalent reactions. A more complex reduction process involving multiple phases was observed (Figure 1E). Particular redox processes have not been assigned to these phases, but overall reduction was completed well before the $\left[\mathrm{Fe}_{4} \mathrm{~S}_{4}\right]^{2+}$ component of isolated $\alpha$ would have been reduced $(\sim 20 \mathrm{sec}$ vs. $\sim 300 \mathrm{sec})$. Thus, the presence of the $\beta$ subunit increases the rate at which the A-cluster cube is reduced. When oxidized ACS was mixed with $\mathrm{CH}_{3}-\mathrm{Co}^{3+} \mathrm{FeSP}$ and $\mathrm{Ti}^{3+}$ citrate, the reaction was qualitatively similar to that with $\alpha_{\mathrm{ox}}$, in that methyl transfer occurred much faster than reduction of $\mathrm{Fe}-\mathrm{S}$ clusters (Figure 1F). Absorbance maximized at $\sim 2 \mathrm{sec}$, in contrast to in $\alpha$ where it maximized at $\sim 20 \mathrm{sec}$. Thus, all related processes $\left(\mathrm{D}_{\mathrm{ox}}\right.$ reduction, methyl group transfer, and $\left[\mathrm{Fe}_{4} \mathrm{~S}_{4}\right]^{2+}$ reduction) must occur faster in ACS than in $\alpha$.
Our results discount an attractive mechanistic role for the $\mathrm{Fe}_{4} \mathrm{~S}_{4}$ component of the A-cluster - namely as an electrontransfer redox intermediary between the D-site and either external redox agents (like $\mathrm{Ti}^{3+}$ citrate) or other clusters in ACS. If it served this role, the rate at which $\mathrm{D}_{\mathrm{ox}}$ reduced should have been equal to or slower than that at which the $\left[\mathrm{Fe}_{4} \mathrm{~S}_{4}\right]^{2+}$ component was reduced. Our results for $\alpha$ showed that the rate of $\mathrm{D}_{\text {ox }}$ reduction was 100 -times faster than the rate of $\left[\mathrm{Fe}_{4} \mathrm{~S}_{4}\right]^{2+}$ reduction. Similar but more complex behavior was observed for ACS. Thus, the role of this component of the A-cluster remains elusive. Mutational studies are underway to assess the possibility that it imparts onto the Ni center critical properties required for catalysis.

Acknowledgment. The National Institutes of Health (GM46441) and the Department of Energy (DE-FG03-01ER15177) sponsored this study.

(1) Lindahl, P.A., Biochemistry, 2002, 41, 2097-2105.

(2) Doukov, T.I.; Iverson, T. M.; Saravalli, J.; Ragsdale, S.W.; Drennan, C.L. Science, 2002, 298, 567-572.

(3) Barondeau, D. P; Lindahl, P. A. J. Am. Chem. Soc. 1997, 119, 3959 3970 .

(4) Kumar, M.; Qiu, D.; Spiro, T.G.; Ragsdale, S.W. Science, 1995, 270, 628-630.

(5) Tan, X.; Sewell, C.; Lindahl, P. A. J. Am. Chem. Soc., 2002, 124, 62776284 .

(6) Loke, H.-K.; Tan, X.; Lindahl, P. A. J. Am. Chem. Soc. 2002, 124, 86678672.

(7) Escherichia coli strain JM109(pLHK05) and M. thermoacetica cells were grown and harvested as described. ${ }^{5}$ All subsequent procedures involving the Recombinant $\alpha$, CoFeSP, and methyltransferase were performed as described. ${ }^{6,5}$ Final purities for these three proteins were $>95 \%$, quantified by SDS-Page gels. ${ }^{5,6} \mathrm{Ti}^{3+}$ citrate was prepared and $\mathrm{Co}^{1+} \mathrm{FeSP}$ was methylated using $\mathrm{CH}_{3}$-THF as described. ${ }^{5} \alpha$ was oxidized by thionin and freed from excess thionin by Sephadex G25. Ni-activated ${ }^{6} \alpha$ was methylated by adding a 20 -fold molar excess of $\mathrm{Ti}^{3+}$ citrate, incubating $20 \mathrm{~min}$, and then adding $\mathrm{CH}_{3}$-THF (5-fold molar excess), Methyltransferase $(5 \%(\mathrm{~g} / \mathrm{g})$ of $\alpha)$, and CoFeSP $(5 \%(\mathrm{~g} / \mathrm{g})$ of $\alpha)$. After overnight incubation, the extent of reaction was determined by monitoring at $390 \mathrm{~nm}$. The resulting solution was concentrated and subjected to Sephadex G25 chromatography to remove excess $\mathrm{Ti}^{3+}$ citrate and $\mathrm{CH}_{3}$-THF. Stopped-Flow experiments were performed as described.

(8) Russell, W. K.; Stalhandske, C. M. V.; Xia, J.; Scott, R. A.; Lindahl, P. A. J. Am. Chem. Soc., 1998, 120, 7502-7510.

(9) (a) Shin, W.; Stafford, P. R.; Lindahl, P. A. Biochemistry 1992, 31, 6003-6011. (b) Ome-Johnson, W. H. Annu. Rev. Biochem. 1973, 42, 159204. 


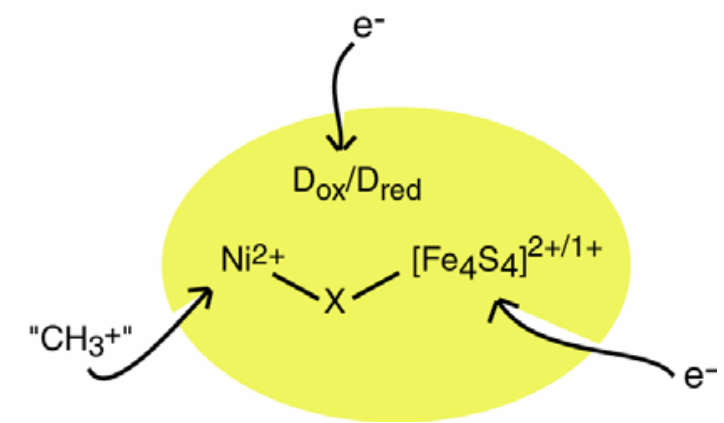

Stopped-flow was used to evaluate the methylation and reduction kinetics of the isolated alpha subunit of acetyl-Coenzyme A synthase from Moorella thermoacetica. This catalytically active subunit contains a novel Ni-X-Fe $\mathrm{S}_{4}$ cluster and a putative unidentified $n=2$ redox site called $D$. The $D$-site must be reduced for a methyl group to transfer from a corrinoid-iron-sulfur protein, a key step in the catalytic synthesis of acetyl-CoA. The $\mathrm{Fe}_{4} \mathrm{~S}_{4}$ component of this cluster is also redox active, raising the possibility that it is the D-site or a portion thereof. Results presented demonstrate that the D-site reduces far faster than the $\mathrm{Fe}_{4} \mathrm{~S}_{4}$ component, effectively eliminating this possibility. Rather, this component may alter catalytically important properties of the $\mathrm{Ni}$ center. The $\mathrm{D}$-site is reduced through a pathway that probably does not involve the $\mathrm{Fe}_{4} \mathrm{~S}_{4}$ component of this active-site cluster. 